\title{
Experiences in Chinese Class for Indonesian Elementary Students in Taiwan
}

\author{
M A Pasaribu', N Suprapto² \\ ${ }^{1}$ Dep. of Education and Human Potentials Development, National Dong Hwa University, Hualien 97401, Taiwan \\ 2Physics Education Program, Universitas Negeri Surabaya, Surabaya 60231, Indonesia
}

\begin{tabular}{l}
\hline Article Info \\
\hline Article history: \\
Received March 19, 2020 \\
Revised April 12, 2020 \\
Accepted April 14, 2020 \\
\hline
\end{tabular}

Keywords:

Chinese class

Indonesian

Elementary students

Taiwan

Qualitative research

\begin{abstract}
This qualitative research was motivated by our experiences while being an international student in Taiwan. We met with four Indonesian students who move to Taiwan because of their parents are postgraduate students. They were four elementary students who were studying in a primary school in Hualien County as a research participant. They have been in Taiwan for around six months. Through an in-depth interview and documentation study, we captured their experiences during a Chinese class. Finally, we got three main themes that impress us: "I don't want to be a loser! (First Impression)"; "I prefer she use body language than English (Learning Process and Teacher)"; and "If I don't know him/her I will ask payment for me (Motivation in Chinese)".
\end{abstract}

\section{INTRODUCTION}

A foreign language is a language indigenous to another country. It is also a language not spoken in the native country of the person referred to, for example, an Indonesian living in Taiwan can say that Chinese Mandarin is a foreign language to him or her. Foreign language usually used by International Students.

International students, according to UNESCO Institute for Statistics (2006), are internationally mobile students have left their country and moved to another country with the singular objective of studying. We are as International Student from Indonesia which living in Taiwan, is not easy to learn Chinese Mandarin. Even though in the class teacher always speak in English but for our daily conversation with local people, the Chinese still be needed.

Based on our reading in many experiences of people, even they have learned Chinese for several years, but it still not makes them comfortable to speak with native Chinese people at all. Because from their experiences, their partner in speaking not really understand their pronunciation and always ask them to repeat what they said. Not only how to speak but also how to write in Chinese, based on David Moser's article in 1991, he stated that an English speaker would find the "absurd" writing system "unreasonably hard to learn" to the level of achieving due to a large number of characters (Moser, 1991). Even though he already knew around 2000 characters, it is not ensured he able to read a newspaper comfortably. It means learning Chinese is enough difficult even adult nor children.

In our experiences while being an International Students in Taiwan, we met with four Indonesian Elementary Students who move to Taiwan because of their parents are postgraduate students in a university in Taiwan, so their parents bring them to move to Taiwan. They have to learn Chinese to support their learning in school, one of public school in Taiwan, which does not provide English service nor Bahasa. That case is one of their causes to learn Chinese. We meet them every Monday and Friday in their Chinese class to be 
their translator between them and the teachers because they cannot speak English and Chinese. The class is held as long 40 minutes learning process each meeting. The teachers who teach them are undergraduate students from our university and a professional teacher from the same university. So, in this study, we want to know about their learning experiences during the Chinese class.

\section{Literature Review}

Based on Future Learning Experiences Project's blog by Shane Gallagher (2011), learning experiences are a way to think about what a learning intervention might be in the context of desired end goals and outcomes. When we learn something, must have a goal to be better than before learning, it will become evident that the study gave an impact to the learner. In our opinion, the best result not only for the learner but also for people around. Gallagher also stated that learning content can be thought of much more broadly and inclusively. This could mean that learning content could include not only the "what" but "how" of learning. The meaning of "how" can be interpreted as how about their motivation to learn, how they overcome the difficulties of learning and many more.

Taiwan, as a country that does not use English as the first language, gives a challenge to International Students to learn Chinese before coming to Taiwan or when in Taiwan. Some of the International Students try to make a connection with local students to improve their language ability. Still, it does not happen well even though their motivation is right to have more relationship and improve themselves. Lindemann (2002) stated most international students are also lacking a support group in the country they are studying, not only from students but also from International Student Office, that do not have enough sources to serve International Students' needs.

\section{RESEARCH METHOD}

The participants for this study were four elementary students studying in an elementary school in Hualien County. They came from Indonesia, and they have been in Taiwan for around six months. All the name of the participant would be disguised.

Table 1. Participants of this research

\begin{tabular}{ccc}
\hline Name & Grade & Sex \\
\hline Mickey Mouse & $2^{\text {nd }}$ & Male \\
Nobita & $3^{\text {rd }}$ & Male \\
Ben10 & $3^{\text {rd }}$ & Male \\
Minnie Mouse & $5^{\text {th }}$ & Female \\
\hline
\end{tabular}

This discussion was designed as a qualitative finding (Creswell, 2007; Yin, 2011). All of the participants were Indonesian elementary students. The sources to get the data were observation and interview. Participant observation is a qualitative method with roots in traditional ethnographic research, whose objective is to help researchers learn the perspectives held by study populations (Jorgensen, 1989; Yin, 2011). An interview is a verbal conversation between two people to collect relevant information for research (Denzin \& Lincoln, 2005; McNamara, 1999). We did observation in the Chinese Class to get all the view of the participants, and the interview did to get participants' opinion and to confirm the experience in the class. The interview took time around 10 minutes each participant, for a semi-structured question, and the interview used the Indonesian language. The interview did by face-to-face with a different approach (Morse \& Richards, 2002). While doing an 
interview, we were recording the conversation by audio recorder so we can hear twice or more to resume the conversation.

We did a data analysis based on our questions to the students. Our questions included their first impression in Chinese Class, their opinion about the learning process, teachers and their motivation in Chinese. We wrote an interesting story based on the point we wanted to know.

\section{RESULTS AND DISCUSSION}

\section{I don't want to be a loser! (First Impression)}

In psychology, a first impression is an event when one person first encounters another person and forms a mental image of that person. Impression accuracy varies depending on the observer and the target (person, object, scene, etc.) being observed. The first impression can be effected next meeting with the same person. When students felt under pressure in their first meeting, it can happen they do not want to come to class anymore, but in another side, if they feel happy and full of motivation, they will really miss the class. We were asking students about their first impression in Chinese Class.

In the first meeting, the professional teacher taught them by herself as a group. According to our observation, all students tried to answer all the question given by the teacher; it looked like they were very enjoying the class. Looked like enjoying the class did not mean giving much improvement for students. After doing the evaluation process, so the teacher contacted her undergraduate students to help us teach students.

All the students agreed that learn in a group very interesting for them because they could speak each other while teacher taught them. Mickey stated he talked each other because the lesson was very hard, he did not understand everything, "I don't like go to school, just bring me back home to Indonesia, or give me Indonesian teacher or Java teacher to teach me so I can learn better I don't wanna come to school!" We always remember how Mickey's expression was. Because of his expression in the class, teacher taught him to said "Wó bù xĭhuān shàngxué (I don't like school)" and he liked that to express his feeling.

Ben10 thought the same with Mickey, and he even did not want to care about the class every meeting. We often saw him daydreaming in the middle of class, and we tried to "called him back" to his class. "I don't like this classes; I even cannot play or draw what I want in the class," Ben 10 said. In the class, he tried to do drawing everything in his book, so the teacher gave an assignment to him, drawing about everything he wanted and wrote the story. Ben10 drew a big plane which he used coming to Taiwan; he told that he is really missing his grandmother, which always gave him and his brother many toys. His grandmother was crying so much because Ben10 and family would be leaving her. The teacher was so touching because of his story.

In another side, Nobita and Minnie actually could follow the class better than Mickey and Ben10. Nobita and Minnie always tried to answer every question from the teacher, but the teacher tried to be fair, so everyone could have a chance to answer the question. "I want to answer every question from the teacher; I don't wanna be a loser. I have to be a winner! So I have to try the next meeting." Nobita felt so fed-up. The most Nobita's competitor was Minnie, because she could follow the learning process in some case she felt nervous so forget what she wanted to answer.

\section{I prefer she use body language than English (Learning Process and Teacher)}

"I like art class, because I can draw, I like do handicraft, I like art"Ben10's expression when we asked him about what kind of class he liked. Even though Chinese has characters like do drawing, he like just some part of write character, “I just like write 一, 二, 三, 四, 大and some 
other characters because that is easy for me". Ben10 knows what he wants and he always deny everything he does not like. That is one the reason he always does daydreaming in class. "Every morning I always fell sleepy if teacher taught me in Chinese Class, because I am bored teacher always asked me repeated reading and reading."

"Teacher never gives me gift if I can do well, this class so different in other class." Mickey said innocently. Someday teacher brought some chocolate as a gift to students, every student got some chocolate and they were very happy. In other day, teacher brought the same chocolate as gift, but Mickey did not accept the chocolate, "This chocolate is so bitter, I don't like. I gave to my mom she doesn't like, so does my dad." Suddenly teacher was laugh, "Actually that is my chocolate, I don't eat sugar so that chocolate is $90 \%$ pure chocolate and just a little sugar in the ingredients, that's why it's bitter. Next time I will bring the sweet one." Students just left the class without complaining or expression.

After around a month teaching and learning process in a group conducted by one teacher, each student was taught by a teacher. "Even though I cannot speak to Minnie in the class, I like this class. I have no rival answering the question; I get more because teacher just focuses on me. Actually I do not understand at all what she told, I just said OK! I surrender! I prefer teacher use body language than English, because I don't understand English. Do you remember when we learn about Pāi pāi shǒu (拍拍手)I prefer teacher just clap her hand than she said 'clap hand". When we observed Nobita's learning process, we saw he can answer every question from teacher, it did not matter took long time or not. "He is too smart" Nobita's teacher said.

Minnie is a cheerful girl, she always laughing even she cannot answer the question from teacher. "I just laugh because I like laughing. My teacher is so funny, I like her. Her English is good, so I can understand what she said" Actually, Minnie's English is good enough because she ever lived aboard before come to Taiwan. Because of she ever lived in other country before, she more adaptable in this situation than her friends. She has stable condition even in new environment.

\section{If I don't know him/her I will ask payment for me (Motivation in Chinese)}

A conversation in a morning:

$\begin{array}{ll}\text { Minnie } & \text { : “Lăoshī zăo” (老师, 早) } \\ \text { Teacher } & \text { : “Minnie, Zăo.Nǐ hăo ma? (Minnie, 早。你好吗?) } \\ \text { Minnie } & \text { : Wǒ hěn hăo. Lăoshī hăo ma? (我很好。老师好吗?) } \\ \text { Teacher } & \text { : Wǒ yě hěn hăo. Xièxiè (我也很好。谢谢) } \\ \text { Minnie } & \text { : *nodding* } \\ \text { Techer } & \text { : You should say “Bù kèqì (不客气) It means you are welcome } \\ \text { Minnie } & \text { : ok, Bù kèqì. Lăoshī }\end{array}$

"I like when teacher ask me in Chinese because if I don't know she will teach me. It makes me improve. I like read, I always read English story book from library, but someday I want read Chinese story book." Minnie told us her wishes while laughing. In a parents' meeting, Minnie's mother said she had expectation that Minnie became expert in Chinese so in future if she wanted come to Taiwan or other country which use Chinese language; she had no problem in language. We think this expectation could be happened because Minnie has motivation in herself to learn more.

Ben10 : "I have no idea why I should learn Chinese. I don't like it, and I can't do this." 
Me : "You can play more with your Taiwanese friends"

Ben10 : "I don't need use Chinese to play; we can play just by body language to know the rules"

Me : "How about you can teach you brother; next year your brother will be school, right?"

Ben10 : “No, I don't like teach him. He will be had his own teacher. I don't need teach him"

We just tried to motivated Ben10 to learn more Chinese, but when we consulted this situation with a senior, she said when we tried to motivated children actually it looked like gambling if we failed we had to try more and more until we got the point of them.

"In the next future, if I come back to Indonesia, I want to teach Chinese to my cousins and my friends. I want them to know Chinese too, but if they want." What a cute Mickey, we thought. He got his motivation, not only for himself but also for his future and his environment. Even though in the first meeting, he always said that he did not like school, but he really had the motivation to learn.

"If someone asks my help to learn them Chinese or speak in Chinese, I will think first. Do I know him/her? If I know, I will help. But if I don't know him/her, I will ask payment for me." Suddenly, we were just laughing and speechless for Nobita's answer. Sometimes we cannot expect children's thought. In this section, we just want to know what he thought about his motivation and his future in learning Chinese, does it has an opportunity to him or not?

\section{CONCLUSION}

Every child has their own experience, an expectation in future or their motivation. The first impression does not guarantee what will happen next. Even though in the first impression, Mickey did not like school, but he has great motivation to be "someone" in future. Actually, in this class, the professional teacher limited them to play and talk to each student because in this section, students have limited time to learn, and they have to focus on their learning. That's why sometimes students fell so bored.

In this paper, we just made a brief conversation because we did not want children felt bored and did not want to answer my question. We hope in the next research we could do a more and more in-depth interview. For other researchers, it will be better to find some information from the other side in this class, such as the teachers.

\section{REFERENCES}

Creswell, J. W. (2007). Qualitative inquiry \& research design: Choosing among five approaches (2nd ed.). Thousand Oaks, CA: Sage.

Denzin, N. K., \& Lincoln, Y. S. (Eds.). (2005). The Sage handbook of qualitative research (3rd ed.). Thousand Oaks, CA: Sage.

Gallagher, S. (2011). Future learning experience project. Retrieved from https:// sites.google.com/a/adlnet.gov/future-learning-experience-project/projectupdates/whatisalearningexperience

Jorgensen, D. (1989). Participant observation. Newbury Park, CA: Sage Publications.

Lindemann, S. (2002). Listening with an attitude: A model of native speaker comprehension of non-native speakers in the United States. Language in Society 31.

McNamara, C. (1999). General Guidelines for Conducting Interviews, Minnesota.

Morse, J. M., \& Richards, L. (2002). Readme first for a user's guide to qualitative methods. Thousand Oaks, CA: Sage Publications. 
Studies in Learning and Teaching (SiLeT)

Vol.1, No.1, April 2020, pp. 12-17

ISSN: 2722-1857

Moser, D. (1991). Why Chinese is so damn hard. Retrieved from http://www.pinyin.info/readings/texts/moser.html

Yin, R. K. (2011). Qualitative research from start to finish. New York: The Guilford Press.

\section{Corresponding Author:}

Margaretha Aurelia Pasaribu

Dep. of Education and Human Potentials Development, National Dong Hwa University,

No.1 Sec.2 Da Hsueh Rd, Shoufeng, Hualien 97401, Taiwan

Email: pasaribu_margaretha@yahoo.co.id 